\title{
Stephanie Bung \\ Playful Institutions: Social and Textual Practices in Early Spanish Academies
}

When the members of the very young Académie Française acted officially for the first time ever, that is, as representatives of a chartered corporation, they immediately overstepped the boundaries of their self-defined jurisdiction: they broke their own rules by taking sides in the context of the famous Querelle $d u$ Cid. In 1637 they published their statement Les sentiments de l'académie française sur la tragi-comédie $d u$ Cid, which led Corneille to make some significant changes to his play. Looking back, these changes and Les Sentiments de l'académie represent the beginning of the doctrine classique, the most fundamental doctrine of poetics in seventeenth-century France. But Corneille was not a member of the academy and he had not asked for his successful play to be judged. The academy intervened anyway, even though their statutes only allowed for judging the work of members. ${ }^{1}$ Interestingly enough, this act of 'misbehaving' - from the viewpoint of the academic rules - was followed by an act of recognition by the authorities: a few months after the outbreak of the Querelle du Cid, the Parlement de Paris acknowledged the Académie Française as an established corporation within the realm of Louis XIII. ${ }^{2}$ This recognition is arguably even more interesting than the well known fact that it was of course the cardinal de Richelieu who forced the academy to intervene in this struggle. The members of the oldest and most powerful corporation of France acknowledged the institutional status of the academy, and in doing so they acknowledged the public relevance, and a certain autonomy, of 'academic concerns.'

As scholars have shown within the last two decades, ${ }^{3}$ the Querelle $d u$ Cid is a fine example of the transformation European academies had to go through when they first became chartered literary institutions. However, the picture of those transformations is far from complete. In order to grasp its complexity, it

1 See article XLV of the academy's statutes (www.academie-francaise.fr/linstitution/statuts-etreglements. Accessed 13 February 2018).

2 See ibid.: "Lettres patentes pour l'établissement de l'Académie française, signées du roi Louis XIII en janvier 1635, enregistrées au Parlement le 10 juillet 1637." (My italics.)

3 See in particular: Jean-Marc Civardi, La querelle du Cid (1637-1638). Édition critique intégrale. Paris: Champion, 2004; Christian Jouhaud, Les pouvoirs de la littérature: Histoire d'un paradoxe. Paris: Gallimard, 2000; Hélène Merlin. Public et littérature en France au XVIIe siècle. Paris: Les belles lettres, 1994; Hélène Merlin-Kajman. L'excentricité académique: littérature, institution, société. Paris: Les belles lettres, 2001. 
is worth looking at another example of academies by moving from seventeenth-century France to Golden Age Spain, where the shaping of the academic idea into an acknowledgeable corporation was even more complicated. There is no continuity between what is called academia in Spain before and after the foundation of the royal academy that was modeled after the Academie Française in $1713 .{ }^{4}$ We actually know very little about Spanish academies that precede the Real Academia Española (RAE). In some cases - for example a certain academy of Madrid that is famous for being mentioned in Lope de Vega's Arte $N_{u e v o}{ }^{5}$ - we have no means to tell if the gatherings in question were more than a rhetorical device. ${ }^{6}$ In other cases, even when there is better documentation of social and textual practices, the institutional nature of these practices is at least very questionable. But how can we learn more about the institutional side of cultural networking in early modern Europe if the meaning of what is called academy, academia, or académie differs from one country to another, and - at least on the Iberian peninsula - even within the boundaries of one country? These questions constitute the heuristic frame of this paper on the first Spanish academies, and it is within this frame that we can begin to understand the different transformations of a literary institution called 'academy' in early mod-

4 See Christine Bierbach. "Todos maestros, todos discípolos: Spanische Akademien vor 1700.” Europäische Sozietätsbewegung und demokratische Tradition: Die europäischen Akademien der Frühen Neuzeit zwischen Frührenaissance und Spätaufklärung, 2 vols., edited by Karl Garber and Heinz Wismann, vol. 1. Tübingen: Niemeyer, 1996, pp.513-533, p. 518. This article, although written two decades ago, is still one of the most thoughtful and relevant studies about academies in Golden Age Spain.

5 When Lope de Vega published his famous Arte nuevo de hacer comedias en este tiempo (1609), one of the most influential poetics in Spanish literature, he addressed the members of "the valiant academy of Madrid." Comparing this place to the academies of ancient Greece and Rome, he begins his Arte nuevo as if it were an open letter to an authority on poetics; an ironic open letter, of course, since this is how Lope defends himself against the 'academic' rules of Aristotle. There have been attempts to identify this particular academy (see most recently Jesús Cañas Murillo. “Corte y academias literarias en la España de Felipe IV.” Anuario de Estudias Filológicos, vol. 35, 2012, pp. 5-26, here: pp. 8-10), but we still do not know much about its existence. There may in fact have been many so-called academies in Madrid in the early seventeenth century, but there are no statutes, no programs, nor any act of institution that would allow us to be certain about this one.

6 As is possibly the case in Lope's Arte Nuevo (see Karl Vossler. Lope de Vega und sein Zeitalter. Munich: Biederstein, 1947, p. 121; Hans Ulrich Gumbrecht. 'Eine' Geschichte der spanischen Literatur, Frankfurt: Suhrkamp, 1990, vol. 1, p. 378). Lope would not have been the only author to invent an academy, as can be seen from the list of academias ficticias, established by José Sánchez (see Academias literarias del Siglo de Oro español. Madrid: Gredos, 1961, pp. 167-193). Sánchez' compilation of Golden Age academies is still very valuable, mainly because of his extensive quotations from manuscripts that would otherwise be difficult to find. 
ern Europe as well as the complexity of the task. In order to grasp the latter, it is necessary to address at least the main difficulties - terminology, documentation, and territory - that we encounter by searching for these institutions within the boundaries of seventeenth-century Spain. By doing so, this paper is conceived as preliminary, yet necessary work to prepare the ground on which one may pursue the investigation of European academies in the future.

\section{Terminology: Permanent and non-permanent academias}

As we can see in the dictionary of Covarrubias from 1611, the Spanish word academia had by then already been adopted for contemporary practices. However, by referring to the ancient world and describing the place and the practice of Plato's school, the dictionary still locates the academic idea within the understanding of a glorious past linked closely to the age of Greek philosophy itself. Whilst this idea may be imitated in the present, it is not replaced by something worthy of a description for its own sake.

Academia, Fue un lugar de recreación, y una floresta que distava de Athenis, mil passos dicha assi de Academo Heroa; y por aver nacido en este lugar Platon, y enseñado en el, con gran concurrencia de oyentes, sus discipulos se llamaron Academicos, y oy dia la escuela o la casa, donde su juntan algunos buenos ingenios a conferir, toma este nombre, y le da a los concurrentes. ${ }^{7}$

However, the real problem of terminology can be found a little later, in the dictionary of the RAE of 1726 known as Diccionario de autoridades. Here, the classic definition of Plato's academia is followed by two different meanings. The first one sounds comforting, since it is very 'close to home,' that is, to our modern understanding of the term: "[Academia] Es tambien la Junta ò Congreso de personas eruditas, que se dedican a el estudio de las buenas letras, y a tratar y conferir lo que conduce a su mayor ilustración, como lo executan las

7 Tesoro de la lengua castellana o española compuesto por el licenciado Don Sebastian Cobarrubias Orozco [...]. Madrid: Sanchez, 1611. (“Academia was a place of recreation and a forest a thousand paces from Athens, which was called Academo Heroa; and because Plato had been born in this place and had taught a great number of listeners there, his students called themselves academics, and nowadays the school or the house where some good minds congregate to debate takes this name and extends it to the participants.” My translation). 
Academias de Italia, España, Francia y Portugal, [...]."8 This is the meaning we have in mind when we think of the Académie Française for example, or the Real Academia Española itself. But this meaning is followed by another one which, for us, is less obvious: “[Academias] Latamente se llaman assí las Juntas literarias, ò Certamenes que ordinariamente se hacen para celebrar alguna acción grande, [...] o para exercitarse los ingenios que la componen, y casi siempre son de Poesia sobre diferentes assuntos. [...]"9

These two definitions, as well as the gap between them, are highly significant. ${ }^{10}$ What matters here is the difference between permanent and nonpermanent, between institution and occasion. On the one hand we think of an academy whose members meet on a regular basis; on the other hand we must imagine an event, like a celebration or a poetry contest, or a poetry contest within a celebration. The problem is to differentiate between these two meanings, especially within a document that only refers to some academia without further details. This brings us to the second difficulty in the study of early modern academies in Golden Age Spain: documentation.

8 Diccionario de la lengua castellana. Madrid: del Hierro, 1726 (www.rae.es/recursos/diccionarios/ diccionarios-anteriores-1726-1996/diccionario-de-autoridades. Accessed 13 February 2018). ("Equally, an assembly or meeting of erudite persons who are dedicated to the study of literature, and discuss that which can further its excellence, as it is practiced by the academies of Italy, Spain, France, or Portugal.” My translation).

9 Ibid. ("In a broader sense, this is also the name of literary assemblies or contests, which usually serve to celebrate some momentous event [...] or to exercise the participants' wits, and almost always consist of poetry on various subjects." My translation). This definition seems to be applied only to the plural of academia, which is interesting for it already points to the nonpermanent structure of those gatherings.

10 Recent studies of Golden Age academies seldom fail to mention this discrepancy (see Pasqual Mas i Usó. Academias y justas literarias en la Valencia barroca: Teoria y prática de una convención. Kassel: Reichenberger, 1996, pp. 1-4; José María Ferri Coll. La poesía de la Academia de los Nocturnos. Alicante: Publicaciones de la Universidad de Alicante, 2001, p. 57), but they rarely take it into consideration when thinking about paradigmatic issues. Helmut C. Jacobs, without going into further details, for his explananda are mainly the Spanish academies of the eighteenth century, compares the first type of academy to literary salons, which is an interesting idea which should be taken into account in future explorations (see Helmut C. Jacobs. Organisation und Institutionalisierung der Künste und Wissenschaften: Die Akademiegründungen der spanischen Aufklärung in der Tradition der europäischen Akademiebewegung. Frankfurt: Vervuert, 1996, p. 19). 


\section{Documentation: The playfulness of statutes}

Since they are supposed to testify to a specific event, non-permanent academias are often quite well documented. ${ }^{11}$ However, the textual and social practices that can be found here are more likely to evolve from the medieval tradition of tournaments and jousts, even if the field of armas is replaced by the field of letras. As for the more permanent gatherings based on statutes and regularity, they are on the contrary very poorly documented. At this point, and since the latter statement may come as a surprise, it is very important to be clear about our understanding of 'documentation,' which differs from that employed by earlier studies of academies in Golden Age Spain. There is no doubt about the existence of permanent academies before 1700, because, as Jacobs has already pointed out, their impact on the literary texts of this period is remarkable. ${ }^{12}$ It does, however, make a difference whether the name of an academy is just mentioned once or twice in a book or in a letter, whether fictional or even semi-fictional masterpieces are supposed to draw the portrait of an academy, or whether there are actual documents that can be classed as the textual 'output' of an academy (mainly handwritten actas). Our understanding of 'documentation' covers only the latter case. Thus, our study necessarily differs from the studies mentioned above that do not make this discrimination between sources, and therefore consider significantly more academies to be 'documented' than we do. These attempted inventories and surveys are not necessarily obsolete, and they give very useful hints to what may lead to an interesting case study in the future. But, since our study aims for the adoption of a systematic approach within this field of research, we shall accordingly concentrate on cases that can already be traced back to actas, statutes, or at least to a specific audience.

The most famous example of personas eruditas who met on a regular basis is the Academia de los Nocturnos. ${ }^{13}$ This academy was founded in Valencia in

11 One of the most famous cases is La Academia del Buen Retiro, a celebration for Felipe IV that took place in 1637. As Sánchez states, there are at least two manuscripts that contain the program of this occasional academy, which can be consulted in the National Libraries of Madrid and Paris (see Sánchez, Academias literarias, pp. 134-154; Sánchez himself quotes extensively from these manuscripts).

12 See Jacobs, Organisation und Institutionalisierung der Künste und Wissenschaften, p. 23.

13 That this is the most famous case is clear from the significant bibliography dealing with this academy, including not only various scholarly articles, but also modern editions of the actas such as: Cancionero de los Nocturnos de Valencia, 2 vols., edited by Pedro Salvá Mallén. Valencia: Ferrer de Orga, 1872; Cancionero de los Nocturnos de Valencia. Segunda parte, edited by Francisco Martí Grajales. Valencia: Vives y Mora, 1906; La Navidad de los Nocturnos en 1591, edited by Arturo Zabala. Valencia: Castalia, 1946; Actas de la Academia de los Nocturnos, 
1591 and existed until 1594. At least in comparison to tournaments and jousts it can clearly be characterized as a permanent gathering. The manuscript begins with a set of rules, the "Instituciones de la academia de los nocturnos." Most of the items of this text - not to mention its entire form - seem to conform to our idea of a modern academy. The following passage is often supposed to present this impression, which is why we quote it at full length:

II. Ítem, ordenamos que la Academia se [h]aya de çelebrar en las casas del Ille. don Bernardo Cathalán, nuestro muy caro y muy amado Académico, el qual [h]aya de ser y sea presidente de [e]lla, prestándole desde agora la obedencia que en semejante caso se requiere.

III. Îtem, ordenamos que todos los académicos [h]ayan de tomar el nombre conforme al de la Academia.

IV. Îtem, ordenamos que todos los académicos se junten un día cada semana, que será el miércoles, y que de una semana para otra esté nombrado un lector, el qual sea obligado a leer una licción de aquello que se le encomendare, de la qual resulte a los oyentes muchas erudición y doctrina, y que a los demás académicos les repartan los trabajos conforme sus ingenios y que sea repartición a voluntad del señor Presidente y con el parecer y acuerdo del lector que entonces fuere.

V. Îtem, ordenamos para el buen govierno de la Academia que el señor Presidente [h]aya de nombrar un Consiliario con el qual consulte todas las cosas que huvieren de hazer: assí de repartir los sujetos, como de recibir académicos, como de otras qualesquier cosas tocantes a la Academia. Y que el Consiliario se le dé silla al lado del señor Presidente y al lector, ni más ni menos, pero con condición que la vez que el Consiliario lea no [h]aya de haver más de dos sillos.

VI. Ítem, ordenamos que se [h]aya de elegir un secretario, el qual tenga obligación de escrevir en el libro de la Academia todas las obras que en ella se hizieren, assí en prosa como en verso, las quales se [h]ayan de escrivir en la casa donde se tiene la Academia y no en otra parte, porque no salga el libro de poder del Sor. Presidente. ${ }^{14}$

5 vols., edited by José Luis Canet, Evangelina Rodríguez and Josep Lluís Sirera. Valencia: Edicions Alfons el Magnànim, 1988-2000.

14 Quoted in: Pasqual Mas i Usó. Academias valencianas del barroco: Descripción y diccionario de poetas. Kassel: Reichenberger, 1999, pp. 60-61. ("II. Further we decree that the Academy is to be hosted at the houses of the illustrious don Bernardo Cathalán, our most beloved Academician, who is to be the Academy's president, by giving him from now on the obedience that is required in such cases. III. Further we decree that all academicians have to take a name compatible with the name of the Academy. IV. Further we decree that all academicians meet once a week, which will be on Wednesdays, and that each week there shall be nominated a lecturer who will be obliged to read a lesson of what is advisable and instructive; and that the work will be distributed to the other academicians according to their spirit and capability, which has to be approved by both the president and the lecturer in charge. V. Further we decree that in order to provide for a good government of the Academy, the president shall nominate a councillor with whom he is to consult about everything that has to be done, such as the distribution of the subjects, the reception of academicians, and other things regarding 
What exactly makes these statutes seem so familiar to a modern reader? The Academia de los Nocturnos has a president (item II), Bernardo Cathalán, whose house is where the sessions take place. The academy consists of regular meetings (item IV) which are dedicated to intellectual work ("erudición y doctrina”). The president appoints a councillor (item V) and the members of the academy elect a secretary (item VI). The task of the secretary consists in documenting the 'output' of this academy: He is supposed to write down any piece of work that has been performed within the walls of Bernardo Cathalán's house during the meetings. What we have here is what we expect from an academy, that is, written proof not only of its existence and its set of rules, but also of the literary practices that took place within its meetings. Thus, if the Academia de los Nocturnos is a famous case today, the reason for this fame may stem not only from the fact that it is one of the earliest Spanish academies, but also from the specific quantity and quality of its documentation. It is tempting to consider this academy as a model, as a paradigmatic case even, because from our understanding of an institution it looks familiar. ${ }^{15}$ But we should be aware that this may be a teleological way of thinking, especially since los Nocturnos are likely to be the only case that provides us with this kind and this amount of information. What seems to be a paradigm for this particular period may very well be the exception, and the following example tends to corroborate this hypothesis, although, at first sight, it is very close to the documentation of the Nocturnos.

The manuscript in question bears the inscription "Pítima contra la Ociosidad." 16 This title - which can be translated as "remedy for idleness" - states

the Academy; and that the councillor shall be seated next to the president and to the lecturer, no more nor less, but with the reservation that when the councillor reads there will be no more than two seats. VI. Further we decree that there is to be elected a secretary, whose obligation will be to inscribe into the book of the Academy every work that has been conceived within its walls, both in prose and in verse, which has to be written in the house where the Academy takes place and not at other places, in order to keep the mastery of the book in the hands of the president." My translation).

15 See Bierbach, Spanische Akademien vor 1700, p. 534: "Während die Nocturnos zweifellos den Prototyp der literarischen Akademien Spaniens verkörpern [...].”; A. L. Prieto de Pauly. "El modelo italiano en la formación de las academias literarias españolas del primer barroco: Los 'Nocturnos' como paradigma." Relaciones culturales entre Italia y España, edited by E. Giménez, J. A. Ríos and E. Rubio. Alicante: Publicaciones de la Universidad de Alicante, 1995, p. 133-148.

16 The manuscript can be found here: bdh-rd.bne.es/viewer.vm?id=0000100085\&page=1. Accessed 13 February 2018. The text has been partly published by Sánchez, Academias literarias, p. 253-258, as well as in: Linajes de Aragón: Revista quincenal ilustrada, vol. 3, no. 20, 1912, pp. 357-363. It is nevertheless important to have a look at the first five folios of the manuscript to get an idea of its significant material quality. 
the self-given aim of the academy, the members of which gathered in the house of Don Gaspar Galcerán de Pinós y Castro, Conde de Guimerá, in June 1608. As is explained on the first pages of the book, there was a specific reason for these gatherings:

La ociosidad, madre de los vicios, enemiga de la virtud, madrastra de los buenos, encuentro y hazar [sic] de los honestos, padrastro de los recogidos, es la que roe, consume y devora los entendimientos aplicados a lo bueno [...]. Y así todos unánimes y conformes fueron de parecer que se pusiese en ejecución lo propuesto, acordando que dicha junta y congregación se intitulase Pítima Contra la Ociosidad, pues era acudir con remedios saludables al daño que en estas soledades podía hacer. ${ }^{17}$

If the members of la Pítima came together in order to resist the dangerous charms of idleness, ${ }^{18}$ they also adhered to a set of rules that bears a remarkable resemblance to the statutes of los Nocturnos. Both manuscripts begin with a list of paragraphs (las instituciones), framing the academic practice the way chartered institutions still do today. In both cases, the members appoint a president, a councillor, and a secretary, the members are given fictional names to enhance the sense of belonging to the academy, ${ }^{19}$ and both manuscripts serve to put the 'outcome' of the academician's work into writing. However, where los Nocturnos content themselves with thirteen items, the members of la Pitima have sixty-three paragraphs that cover nine entire pages of the manuscript. This 'flooding' of the start of the manuscript is actually the noteworthy part of this observation: The appearance of the items on pages two to nine tells us something about how they were conceived. The first ten items form two columns, each column being written on a single page (pages five and six, the recto and verso of one folio). Items 11 to 35 constitute four columns, but this

17 Quoted in: Sánchez, Academias literarias, pp. 252-253. ("Idleness, mother of the vicious, enemy of virtue, evil stepmother of the good, antagonist of the honest, evil stepfather of the decent, is what gnaws away, consumes, and engulfs the spirit that is dedicated to the good. [...] And so everybody agreed that what had been suggested should be realized, that was to name the company in question Pítima Contra la Ociosidad and to find some beneficial cure against the damage that could be done in this solitude.” My translation).

18 This passage, constructed on the Renaissance topos of idleness, points to the classical culture of this academy. On the Renaissance topos of idleness see Virginia Krause. Idle Pursuits: Literature and Oisiveté in the French Renaissance. Newark: University of Delaware Press, 2003.

19 The 'academic names' are one of the reasons why these Spanish academies are so often linked to Italian academies of the sixteenth century, where this onomastic tradition originates. However, the link between Italy and Spain remains to be explored, at least in a more systematic way than has been done so far. Hence, in this particular study we try not to put too much weight on the Italian connection. 
time there are two columns per page (pages seven and eight, the recto and verso of two folios). Item 35 overlaps onto page nine where there is also a short concluding note and the signature of the host, the count of Guimerá. The remaining twenty-eight items now go 'backwards,' being inserted into the free space left by the second column of the statutes (page six) and on pages two to four, where items 45 to 63 fill the space left free next to the preliminary discourse. ${ }^{20}$

What does this disposition of the instituciones tell us? The original set of rules obviously comprised only thirty-five paragraphs, since the signature of the count closes the matter. Then something happened that made the members of la Pitima feel that they needed some more statutes. But why? The content of items 36 to 63 does not explain anything, and they do not seem to be indispensable either. On the contrary, they seem to have been added for the sheer pleasure of invention, or even for the pleasure of writing those statutes, since some of them are rather redundant. The flooding of the manuscript also reveals a certain dynamism, the acceleration of a process that got out of hand. Those instituciones undeniably have a playful character, as if inventing the rules for some sort of game eventually became the game. The members of la Pitima, at least to judge from their manuscript, invented more and more rules that consisted in describing a social practice called academia. This brings to mind the meta-game of Urbino that Baldassare Castiglione portrayed in his famous Libro del cortegiano. ${ }^{21}$ Of course, the noblemen and -women who (allegedly) gathered in the chambers of the duchess of Urbino in the early years of the sixteenth century described and discussed the rules for being the perfect courtier (as opposed to the perfect academician); they also met only three days in a row, whereas la Pitima seems to have been active for about six months. Still, there is a resemblance that is at least as convincing as the resemblance the manuscript bears to the book of los Nocturnos. As Christine Bierbach has already pointed out, ${ }^{22}$ just like Elisabetta Gonzaga, the duchess of Urbino, and her lady-in-waiting, Emilia Pia, the central figures of la Pítima are noblewomen, the countess of Guimerá and her mother, the countess of Eril. This

20 This is why the consultation of the manuscript cannot be supplanted by consultation of the published version of the statutes (see note 17).

21 See Baldassarre Castiglione. Il Cortegiano, edited by Amadeo Quondam. Milan: Mondadori, 2002. Of course there are really two 'meta-games' in the Cortegiano; the actual game of the courtier ("il più bel gioco che fare si potesse," ibid., p. 28), and the game that led to finding this game ("la scelta del gioco," ibid., p. 19-28). The instituciones of la Pítima can be read as an allusion to each of them; they are a preliminary act as well as a code of practice.

22 Bierbach, Spanische Akademien vor 1700, p. 535. 
aristocratic environment ${ }^{23}$ differs from the more urban milieu of los Nocturnos, and may perhaps account for the impression of playfulness that arises from the manuscript: Castiglione invented the notion of sprezzatura for a kind of relaxed behavior that suits noblemen and -women who would never let themselves be mistaken for scholars. ${ }^{24}$ So even when we look at the academy that is - from the viewpoint of documentation - closest to the academy of Valencia, we are obliged to state important differences; indeed, important enough to question the paradigmatic status of the Academia de los Nocturnos mentioned above. And yet they have one last quality in common which brings us to the final issue that a discussion of Golden Age Spanish academies should raise: since the estates of the Guimera are located near Zaragoza, the gatherings of la Pítima as well as the meetings of los Nocturnos took place in the eastern territories of Spain, under the crown of Aragón.

23 Don Gaspar Galcerón de Pinós y Castro, Conde de Guimerá belongs to the higher aristocracy. His grandmother for example, Doña Luisa de Borja, Duquesa de Villahermosa, was a grandee's daughter, born into the famous house of Borja and married into the house of Aragón. His grandmother and his wife Doña Isabel Inès de Eril are both portrayed by Diego Ignacio Parada in his work about Escritoras y Eruditas Españolas (Madrid: Manuel Minuesa, 1881, pp. 184-186 and p. 212-213). For Parada it is Doña Isabel Inès de Eril who has to be accounted responsible for the foundation of la Pítima, even though the Conde de Guimerá was himself a man of culture (“distinguido escritor, erudito y anticuario," ibid., p. 212) and close to Vincencio Juan de Lastanosa.

24 One may argue that the actas of los Nocturnos also reveal a 'playful' character as they have a tendency to mockery (see José María Ferri Coll. "Burlas y chanzas en las academias literarias del Siglo de Oro: Los Nocturnos de Valencia.” Actas del XIII Congreso de la Asociación Internacional de Hispanistas, 4 vols., edited by Carlos Alvar and Florencio Sevilla. Madrid: Castalia, 2000, vol. 1, pp. 327-335), but this is the rough tone of satire, more likely to be encountered in a masculine environment. This is actually the main difference between the two circles, because, as has been shown by José María Ferri Coll ("El Libro de la Academia de los Nocturnos." Anales de literatura española, no. 20, 2008, pp. 189-210), the community of los Nocturnos consists of both noblemen and commoners, but there is no woman among them. They seem closer to the Italian author Stefano Guazzo than to Castiglione. In his famous book La conversazione civile (1574), Guazzo pictures an ideal of academic brotherhood that is independent of female influence. 


\section{Territory: Aragonese académicos and caballeros}

It may be no coincidence that academies - in the sense of permanent gatherings - are better documented for the Aragonese than for the Castilian area. ${ }^{25}$ The problem that must be addressed here is the political tension between those territories. At the beginning of the seventeenth century, the cities of Aragon were eager to defend themselves against the loss of independence on both the political and the cultural level. Significantly, the constitution they wanted to defend was one in which Aragón was almost entirely governed by traditional urban corporations. To illustrate how this context may well have motivated the founding of academies, we will examine one last example, which refers to an academy in Zaragoza and was written by the poet and playwright Lupercio Leonardo de Argensola.

Among literary historians, "los discursos de Argensola" - like "las instituciónes de la Academia de los Nocturnos" - are famous for allegedly providing a paradigm of the ideal, that is the humanist, Spanish academy. Although the humanist idea of the perfect brotherhood of learned people certainly does inform the whole text, this paradigmatic status is - once again - questionable. First of all, Argensola is clearly addressing an audience that demands diplomatic skills. He is speaking to the members of a group called academia in order to convince them of their civil duties and responsibilities. In doing so, he claims that history is the key concept of self-respect and - as we would say today - of 'cultural identity':

E ignorar uno las historias de su tierra y de sus mayores es ignorancia, tan culpable como no haberse visto jamás al espejo, ni saber en su imaginación qué manera de rostro tiene, y aun peor, porque es como ignorar los dedos de sus manos, y los miembros de que consta su cuerpo."26

25 Obviously, it seems perfectly possible that this is (also) due to its close relationship with Italy. However, since it is precisely the link between Italian and Spanish academies that needs to be explored eventually, we should not jump to conclusions yet. All we know for sure at present is that there are three early cases of permanent Spanish academies whose actas have been preserved; and that all three cases - the academias of Valencia, Zaragoza, as depicted above, and Huesca (see Sánchez, Academias literarias, p. 261-266) - relate to the territories belonging to the "crown of Aragón." In addition to these actas, there is the famous case of Argensola's discorsos written for "an academy of Zaragoza" that will be discussed now.

26 Quoted in: Sánchez, Academias literarias, p. 239-240. ("And to ignore the history of one’s territory and ancestors is ignorance, as blameworthy as if you had never seen yourself in the mirror, or as if you could not even imagine what your face looks like, or even worse, because it would be like ignoring the fingers of your hands and the parts of your body.” My translation). 
For Argensola, history should be at the centre of this academy's activity; he even considers it the matrix of knowledge: “[...] pero la historia, con afabilidad y dulzura, de todos toma lo mejor, y es, por decirlo brevemente, un diversorio donde todas la ciencias y las artes reposan; enseña sin cansancio (como dije que lo hacía esta junta), hace que en pocos años vivamos muchos años [...].”27 The last sentence puts history on a par with philosophy, or at least echoes Seneca, who claims in De brevitate vitae that the only way to have a long life is to pass time with philosophy. Still, it is history, not philosophy, that seems to be more likely to capture the audience's attention. It is like a mise en abîme of the whole idea of academia, or at least of this particular academy. So who are the men whom the author of this speech is addressing? Whilst there is no way of knowing for sure, there is enough evidence to make the following assumption:

Argensola seems to be addressing a group of young, perhaps hot-blooded noblemen, who are not so much interested in philosophy as in politics. Talking about history can be considered an attempt to 'meet halfway,' nobility being inextricably linked to the history of one's own family and territory. At one point, Argensola even addresses his audience directly by calling them caballeros: "Considerando yo que los más de vuesas mercedes son caballeros aficionados al ejercicio militar y que para este fin hay en esta ciudad fundada la antigua y nobilísima cofradía de San Jorge ..."28

The mention of the fraternity of Saint George, an actual chivalric fraternity apparently founded in $1505,{ }^{29}$ is very interesting. The members of this fraternity consider themselves to be not only noblemen, but knights; one of their most important activities is the organization of tournaments and jousts. But what is even more important for our purposes is that in 1591 this cofradia had been fighting alongside the Aragonese rebels in the context of what is known as the Alteraciónes de Aragón. These alteraciónes can be understood as a mini-Fronde at the end of which Felipe II took away a number of privileges (Fueros del

27 Ibid., p. 240. (“[...] but history, with affability and sweetness, takes the best of everything; to put it briefly: it is a reservoir for arts and sciences; it teaches without exhaustion [as I said that it is done in this assembly], its effect is that in only a few years we live many years [...]"; my translation).

28 Ibid., p. 240. ("When I come to think of the fact that most of you honorable gentlemen are knights who are enthusiastic about military exercises, and that to this end there has been founded, in this town, the venerable and most noble fraternity of Saint George ...”; my translation).

29 The abovementioned Cofradía de San Jorge is the predecessor of an existing fraternity called the Real Maestranza de Caballeria de Zaragoza (see www.rmcz.com/historia1.htm. Accessed 13 February 2018). 
Reino) from the kingdom of Aragón and its towns. When the Aragonese rebels had lost the battle and Felipe II granted forgiveness, he excluded from this act of generosity numerous members of the Cofradía de caballeros de San Jorge. ${ }^{30}$

We do not know exactly when Argensola wrote his discursos, but they are only a couple of years away from the Alteraciones de Aragón. ${ }^{31}$ The idea of an “academia de Zaragoza” at a time when the Cofradía was still enfeebled by the royal disapproval could be perceived - from the authorities' point of view - as a threat. To temper this threat, Argensola not only advises his pupils not to publish any poetry that might comment on the political situation in Aragón, ${ }^{32}$ but also draws a 'counter-picture' of their gatherings that is taken from the humanist idea of an academy. The problem is to reconcile this picture with the self-perception of his audience, that is of the académicos who are actually mainly caballeros. The whole text is very thoughtfully constructed, and the sugarcoating of philosophy by calling it history is just one example of this. Argensola has to convince the members of a more chivalric than scholarly assembly that it would be better to leave the field of armas in order to defend

\section{See ibid.}

31 Argensola as well as his brother Bartolomé Leonardo de Argensola were very aware of the rebellion, as we can see from the fact that both of them wrote about it (see Lupercio Leonardo de Argensola. Informacion de los sucesos del Reino de Aragón en los años de 1590 y 1591. Madrid: Imprenta real, 1808; Bartolomé Leonardo de Argensola. Alteraciones populares de Zaragoza año 1591, edited by Gregorio Colás Latorre. Zaragoza: Institución Fernando el Católico, 1996).

32 “[...] Jamás han faltado delatores y malsines: de esta verdad tenemos experiencia, porque los señores Virrey y Justicia de Aragón, mal informado, hablaban de esta junta aplicándole ciertos versos y libelos, y que aquí se censuraba el gobierno público. Quisieron saber de mí la verdad; y como tiene tanta fuerza, no solamente perdieron esta opinión, pero alabando lo que aquí se hace, creen que la república tiene en vuesas mercedes defensores de virtud y maestros que, con su ejemplo, enseñarán a cada cual a contenarse dentro de sus límites.” Quoted in: Sánchez, Academias literarias, p. 241. ("There are always traitors and maleficent people: we know this from experience, because the viceroy and the chief judge of Aragón, misinformed, spoke of this assembly, to whom they ascribed certain verses and pamphlets in which the government is criticized. They asked me for the truth; and since the truth has so much power, not only do they not think this any more, but, praising what is done here, they believe that you are virtuous defenders of the commonwealth, and that what is taught here ensures that everyone is content and stays in his place.” My translation).

What Argensola probably had in mind here are the pasquines of 1591, which he does not want the literary output of this academy to be (mis)taken for. On the pasquines of 1591 see: Paloma Bravo. "El Pasquín: Condiciones de escritura, diffusión y recepción en la Revuelta Aragonesa de 1591." L'écrit dans l'Espagne du siècle d'or: pratiques et représentations, edited by Pedro M. Cátedra, Maria Luisa López-Vidriero and Agustin Redondo. Salamanca: Publications de la Sorbonne/Ediciones de la Universidad de Salamanca, 1999, pp. 33-42. 
their Aragonese identity on the field of letras. This is why the humanist idea of an academy impregnates the whole speech, even if Argensola cannot put too much emphasis on the Italian model: "En Italia ha habido y hay Academias famosas; más ¿para qué buscamos ejemplos extranjeros?”33

Thus the author claims that, when it comes to academias famosas, there is a Spanish tradition you can draw on. But why is this tradition so hard for us to grasp? This question brings us back to the terminological problem mentioned at the beginning of this paper: evidently Argensola can rely on the Spanish meaning of academia in the sense of a non-permanent gathering where the idea of a medieval, chivalric contest is still alive. His audience is likely to respond to this meaning rather than to the humanist model that can be found in Italy. Torn between poetics and politics, between armas and letras, this particular academy leans clearly towards the former, even if the author of the discursos strongly recommends the latter. For an academy closely linked to a corporation that has fallen from grace - the Cofradía de caballeros de San Jorge -, it is important that its institutional character, where the humanist model is fused with the Spanish tradition of jousts and tournaments, should spring from intellectual concerns.

\section{Conclusion}

Having examined three important cases of well documented early Spanish academies - in the sense of permanent gatherings - we can make the following assumption: there is no paradigm, no 'ideal academy' in Golden Age Spain, let alone a wide range of humanist academies imitating the Italian model. This is what the attempted inventories of Sánchez and King as well as more recently established surveys of early Spanish academies do not allow us to see, for they are focused on continuity. The presumption of continuity is built on a model of development where the academies of Renaissance Italy form the starting point, and the chartered corporation of the RAE, conceived on the basis of the French model, is considered the end point. This is what makes the actas of La Academia de los Nocturnos look like a paradigmatic case that proves continuity. The problem with this approach is that it may take for granted what needs to be thoroughly examined.

33 Quoted in: Sánchez, Academias literarias, p. 240. ("In Italy they had and still have famous Academies; but why search for foreign examples?” My translation). 
Early Spanish academies are cultural knots, where different, sometimes even antagonistic elements are tied together: noblemen and scholars, permanent and occasional gatherings, medieval and humanist traditions, and last but not least poetics and politics. Still, it is important to keep in mind that we have to look carefully at the social and textual practices linked to those 'knots.' We do not yet know much about their institutional nature, and even the existence of rules and statutes does not automatically transform them into literary corporations, as we can see from the playful character of La Pítima contra la Ociosidad as well as from how Lupercio de Argensola's diplomatic skills are required to address the members of an academy in Zaragoza. Does this mean that these social and textual practices are not a valuable contribution to our understanding of the institutional development of early European academies? Actually they are, even though they demand careful consideration: On the one hand, they do not lead directly to what we think we know, that is literary academies being authorities in poetic concerns. On the other hand, the diversity of these cases does not equal arbitrariness. There has to be a model - the statutes of los Nocturnos and la Pítima are too alike not to share some kind of predecessor -, and this model is likely to derive from Italy. However, this virtual Italian model is probably not a homogeneous phenomenon either. There is a big difference between Castiglione's rules for the ideal courtier and Stefano Guazzo's reflections on civil conversation to begin with, let alone between the actual academies in Siena, Florence, or Casale, for instance. And in Spain as well as in other countries, those Italian books and rules and playful institutions tend to blend with traditions that go back to the Middle Ages, eventually leading to a manifold landscape of social and textual practices. To study those landscapes in Spain, France, Germany, and even in Italy is not an obsolete task, for it allows us to know more about the early modern European cultural net of which academies like these are an essential part. 
